\title{
PENERAPAN MODEL SIMULASI PENJADWALAN ANTRIAN PADA NASABAH BANK MEGA PADANG
}

\author{
Fitri Firdalius \\ Universitas Putra Indonesia YPTK Padang, Sumatera Barat, Indonesia \\ Jl. Raya Lubuk Begalung, Lubuk Begalung Nan XX Padang \\ Email: fitrifirdalius11@gmail.com
}

\begin{abstract}
Along with progress in improving communication and information, the development of the banking world the more rapidly, the customer service system is needed who are able to provide satisfying services for customer. One problem that often arises in the banking customer service system is in the form of occurrence customer queues that result in too long customers waiting to get service. Information alone is not enough if it cannot be managed to be the best alternative, therefore a simulation system for bank customer queue scheduling is used. The design of the queue simulation model is expected to provide information for Mega Padang bank management and better service to customers, so that it can be seen every input, process and output that occurs during the development of the model and simulation. Therefore, a simulation using the discrete event method is conducted.to the customer service system of Bank Mega Padang which results in output explain the characteristics and behavior of the observed system,in this case it provides information about the average time wait for customers, average customer service time and long time when the teller is idle in a certain time. The system design process uses test simulation and system implementation using Microsoft Access 2003 database and Visual Basic 6.0 program applications. And the output generated from the length of time the teller is unemployed, as many as 65 Mega Padang bank customers, the research achieved for the management of Mega Padang bank is that management does not need to add a teller because of the large amount of time the teller is unemployed.
\end{abstract}

Key words: visual basic 6.0, models and simulation,microsoft Access 2003,perbankan

\section{PENDAHULUAN}

Seiring dengan kemajuan komunikasi dan informasi yang semakin meningkat, banyak orang yang mengumpulkan informasi sebanyak mungkin melalui berbagai media yang dimilikinya. Tetapi tidak semua orang mampu mengelola informasi tersebut dengan baik agar dapat dimanfaatkan pada waktu yang tepat secara efisien dan efektif.

Konsep simulasi adalah alat bantu untuk memahami masalah yang akan dipecahkan. Dirancang untuk membantu pemecahan masalah yang berhubungan dengan sistem yang dioperasikan secara alamiah. Simulasi diawali dengan pemahaman atas sistem dan pembangunan modelnya.Pemodelan (modeling) adalah proses merancang sebelum melakukan pengkodean (coding). Pemodel perlu pengetahuan yang cukup terhadap sistem yang akan ditelaah. Membuat model dari sebuah sistem yang kompleks sangatlah penting karena kita tidak dapat memahami sistem seperti itu secara menyeluruh. Dalam kegiatan perbankan juga dapat digunakan sistem tersebut.Pada jamjam tertentu teller yang melayani nasabah dalam keadaan menganggur (Idle), karena tidak ada nasabah yang dilayani. Tapi lain waktu, banyak nasabah yang antri karena hampir semua teller yang ada digunakan oleh nasabah (dalam kondisi sibuk). Timbulnya tuntutan efisiensi waktu dalam menyelesaikan transaksi di bank sangat berkaitan erat dengan sistem 
antrian dimana didalamnya tercakup jumlah layanan yang dimiliki bank. sebab nasabah terpaksa menunggu dalam antrian yang panjang namun bila terlalu banyak teller kondisi menganggur (tidak sibuk) akan menambah biaya bagi manajemen. Begitu juga, jika terlalu banyak nasabah yang antri, akan mengurangi layanan yang prima. Nasabah yang terlalu lama menunggu, tentu akan mencari alternatif bank lain atau batal bertransaksi. Bank harus menyediakan teller dalam jumlah yang betulbetul sesuai agar kinerja bank lebih optimal. Dengan kata lain semua teller terpakai dan tingkat kepuasan nasabah bagus.Berdasarkan latar belakang penelitian yang telah diuraikan, penulis mengindentifikasikan 2 (dua) permasalahan yang dihadapi berdasarkan kasus yang diteliti adalah bagaimana merancang model untuk simulasi penjadwalan antrian nasabah Bank khusus untuk nilai waktu pelayanan teller terhadap nasabah? dan bagaimana hasil simulasi bermafaat untuk memenuhi kebutuhan manajemen berupa informasi yang akurat guna mengetahui perlu atau tidak penambahan teller pada Bank Mega Padang?

Definisi Antrian Nasabah menurut Gross dan Haris (Gross, 2001) mengatakan bahwa sistem antrian adalah kedatangan pelanggan untuk mendapatkan pelayanan, menunggu untuk dilayani jika fasilitas pelayanan (server) masih sibuk, Mendapatkan pelayanan dan kemudian meninggalkan sistem setelah dilayani.Sistem antrian merupakan faktor yang penting dalam dunia bisnis karena merupakan salah satu ukuran efisien atau tidaknya kinerja layanan bisnis. Dalam penelitian ini, dilakukan analisa dua jenis sistem antrian: antrian jalur tunggal (single-channel) dan antrian jalur banyak (multiplechannels) yang banyak digunakan di bank. Penelitian dilakukan dengan mengembangkan program komputer untuk mensimulasikan sistem antrian dan memprediksikan panjang antrian, waktu tunggu, dan probabilitas mengantri. Pendekatan metode discrete-event digunakan untuk membuat model sistem antrian, dan untuk menganalisa efek-efek yang terjadi apabila akan dilakukan perubahan jenis sistem antrian. Hasil simulasi menyatakan bahwa sistem antrian single-channel lebih efisien dibandingkan sistem multiple-channels.Karakteristik Antrian komponen dasar proses antrian adalah A. Kedatangan,setiap masalah antrian melibatkan kedatangan, misalnya orang, mobil, panggilan telepon untuk dilayani, dan lain-lain. Unsur ini sering dinamakan proses input. Proses input meliputi sumber kedatangan atau biasa dinamakan calling population, dan cara terjadinya kedatangan yang umumnya merupakan variabel acak. Menurut Levin, dkk (2002), variabel acak adalah suatu variabel yang nilainya bisa berapa saja sebagai hasil dari percobaan acak. Variabel acak dapat berupa diskrit atau kontinu. Bila variabel acak hanya dimungkinkan memiliki beberapa nilai saja, maka ia merupakan variabel acak diskrit. Sebaliknya bila nilainya dimungkinkan bervariasi pada rentang tertentu, ia dikenal sebagai variabel acak kontinu.B.Pelayan ,pelayan atau mekanisme pelayanan dapat terdiri dari satu atau lebih pelayan, atau satu atau lebih fasilitas pelayanan. Tiap tiap fasilitas pelayanan kadang - kadang disebut sebagai saluran (channel) (Schroeder, 1997). Contohnya, jalan tol dapat memiliki beberapa pintu tol. Mekanisme pelayanan dapat hanya terdiri dari satu pelayan dalam satu fasilitas pelayanan yang ditemui pada loket seperti pada penjualan tiket di gedung bioskop.C.Antri,inti dari analisa antrian adala $\mathrm{h}$ antri itu sendiri. Timbulnya antrian teruta ma tergantung dari sifat kedatangan dan pro ses pelayanan. Jika tak ada antrian berarti $t$ erdapat pelayan yang menganggur atau kelebi han fasilitas pelayanan.Proses yang terjadi pada antrian dapat digambarkan sebagai berikut 


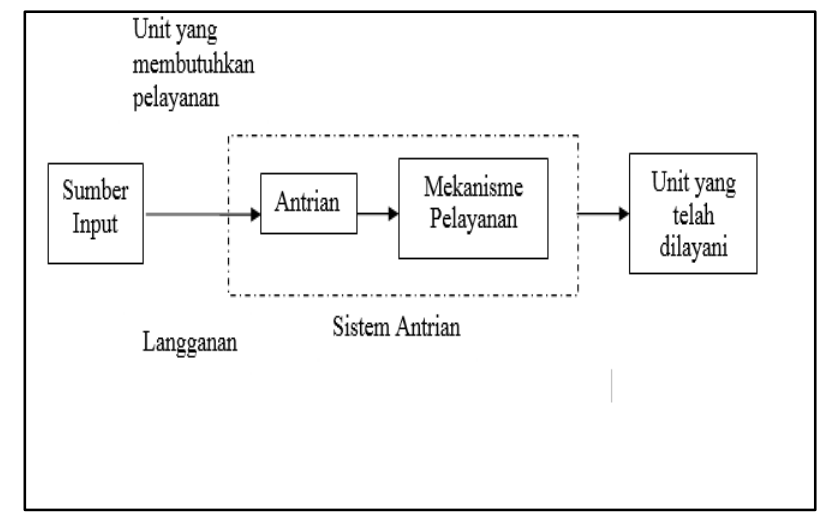

Gambar 1. Struktur Standar Model Antria

\section{Struktur Antrian}

Ada 4 model struktur antrian dasar yang umum tetapi dalam seluruh sistem antrian :

1. Single Channel - Single Phase

Single Channel berarti hanya ada satu jalur yang memasuki sistem pelayanan atau ada satu fasilitas pelayanan. Single Phase berarti hanya ada satu pelayanan.

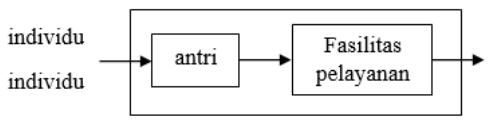

individu yang telah dilayani

Gambar 2. Model Single Channel - Single Phase

Sumber : Subagyo

http://www.ekonomi.wima.ac.id/files/OR.doc

2.Single Channel - Multi Phase

Istilah Multi Phase menunjukkan ada dua atau lebih pelayanan yang dilaksanakan secara berurutan (dalam phase-phase). Sebagai contoh : pencucian mobil.

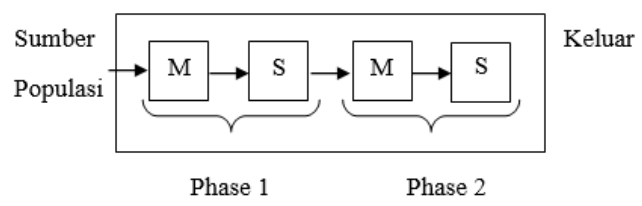

Gambar 3. Model Single Channel - Multi Phase

Sumber : Subagyo

http://www.ekonomi.wima.ac.id/files/OR.doc 3.Multi Channel - Single Phase

Sistem Multi Channel - Single Phase terjadi kapan saja di mana ada dua atau lebih fasilitas pelayanan dialiri oleh antara tunggal, sebagai contoh model ini adalah antrian pada teller sebuah bank.

Sumber Populasi

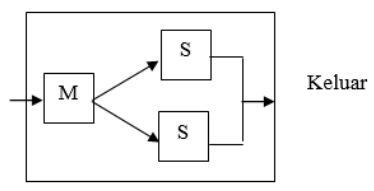

Gambar 4. Multi Channel - Single Phase Sumber: Subagyo

http://www.ekonomi.wima.ac.id/files/OR.doc 4.Multi Channel - Multi Phase

Sebagai contoh, herregistrasi para mahasiswa di universitas, pelayanan kepada pasien di rumah sakit mulai dari pendaftaran, diagnosa, penyembuhan sampai pembayaran. Setiap sistem - sistem ini mempunyai beberapa fasilitas pelayanan pada setiap tahapnya.

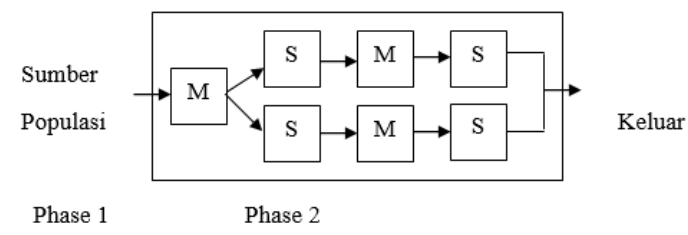

Gambar 5. Multi Channel - Multi Phase

Sumber : Subagyo

http://www.ekonomi.wima.ac.id/files/OR.doc

A. Teori Probabilitas

1. Ruang Sampel dan Peristiwa

Di dalam suatu kegiatan, seringkali dilakukan berbagai percobaan atau eksperimen. Menurut Djauhari (1990), hasil eksperimen akan memberikan informasi tentang masalah 
yang sedang dihadapi dalam kegiatan tersebut. Eksperimen-eksperimen tersebut mempunyai karakteristik sebagai berikut :

a. Hasil eksperimen tidak dapat diduga sebelumnya dengan tingkat keyakinan yang pasti.

b. Semua hasil yang mungkin dapat diberikan.

c. Eksperimen dapat dilakukan berulangulang dalam kondisi yang sama.

Eksperimen yang memiliki karakteristik tersebut, selanjutnya disebut eksperimen acak (random eksperiment). Kemudian, himpunan semua hasil yang mungkin dari suatu eksperimen acak, disebut ruang sampel (Djauhari,1990). Sedangkan peristiwa adalah himpunan bagian dari ruang sampel (Djauhari, 1990:4).

2. Probabilitas Suatu Peristiwa

Teori probabilitas mempelajari tentang peluang terjadinya suatu hal atau peristiwa. Probabilitas dinyatakan dalam pecahan desimal antara 0 dan 1 . Bila probabilitas suatu kejadian bernilai 0 , maka kejadian tersebut tidak akan terjadi. Sedangkan bila suatu kejadian mempunyai probabilitas 1 , maka kejadian tersebut pasti terjadi. Probabilitas suatu peristiwa atau kejadian adalah suatu atau beberapa kemungkinan hasil dari suatu tindakan. (Dimyati, dkk, 1999 ).

3. Uji Goodness of Fit

Satu cara yang cepat untuk memeriksa apakah satu himpunan data mentah

tertentu sesuai dengan distribusi teoritis tertentu adalah membandingkan secara grafik distribusi empiris kumulatif dengan fungsi kepadatan kumulatif yang bersesuain dari distribusi teoritis yang bersangkutan. Jika kedua fungsi tersebut tidak memperlihatkan deviasi yang berlebihan, terdapat kemungkinan yang cukup besar bahwa distribusi teoritis itu sesuai dengan data mentah tersebut. Uji Goodness of Fit adalah uji yang dilakukan untuk menentukan distribusi probabilitas dari data yang diperoleh dengan membandingkan frekuensi teoritis atau frekuensi yang diharapkan (Guttman, 1982 ).

\section{Model Simulasi}

Simulasi adalah suatu cara untuk menduplikasi atau menggambarkan ciri, tampilan, dan karakteristik dari suatu sistem nyata. Dalam mata kuliah ini kita mempelajari bagaimana untuk mensimulasi suatu sistem bisnis atau manajemen dengan membangun suatu model matematis yang diusahakan untuk mewakili kenyataan dari sistem sedekat mungkin.

Ide awal dari simulasi adalah untuk meniru situasi dunia nyata secara matematis. Kemudian mempelajari sifat dan karakter operasionalnya, dan akhirnya membuat kesimpulan dan membuat keputusan berdasar hasil dari simulasi. Dengan cara ini, sistem di dunia nyata tidak disentuh atau dirubah sampai keuntungan dan kerugian dari apa yang menjadi kebijakan utama suatu keputusan di uji cobakan dalam sistem model.

Untuk menggunakan simulasi, hal-hal yang perlu dilakukan adalah:

1. Menentukan permasalahan.

2. Mengajukan variabel yang berhubungan dengan permasalahan.

3. Membangun model numeris.

4. Menentukan rangkaian kemungkinan aksi untuk percobaan.

5. Menjalankan eksperimen mempertimbangkan hasil eksperimen (memodifikasi model atau merubah input)

6. Memutuskan langkah yang akan diambil.

\section{METODE PENELITIAN \\ Kerangka Kerja}

Kerangka kerja yang digunakan dalam penelitian ini dapat digambarkan seperti terlihat pada gambar berikut : 


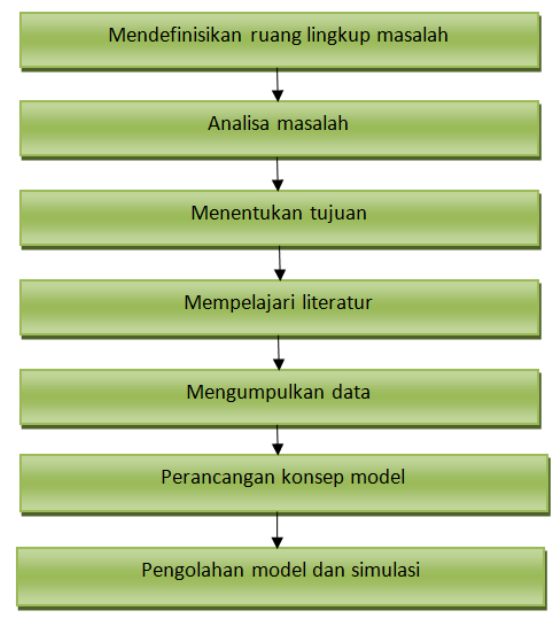

Gambar 6. Kerangka Kerja Penelitian

\section{Model - model Antrian}

Pada pengelompokkan model-
model antrian yang berbedabeda akan digunakan suatu notasi yang di sebut dengan Notasi Kendall. Notasi ini se ring dipergunakan karena beberapa alasan diantaranya, karena notasi tersebut merupa kan alat yang efisien untuk mengidentifika si tidak hanya model-model antrian, tetapi juga asumsi-asumsi yang harus dipenuhi (Subagyo,2000).

http://www.ekonomi.wima.ac.id/files/OR.doc Persamaan umum model :

$(\mathrm{a} / \mathrm{b} / \mathrm{c}) ;(\mathrm{d} / \mathrm{e} / \mathrm{f})$

Menurut Siagian (1987), berikut ini adalah beberapa karakeristik dari sistem

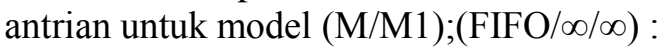

\section{Intensitas Lalu lintas}

$\rho=\frac{\lambda}{\mu}$

$\rho$ disebut intensitas lalu-lintas yakni hasil bagi antara laju pertibaan dan laju pelayanan. Makin besar harga $\rho$ makin panjang antrian dan sebaliknya

\section{Periode Sibuk}

Kalau mekanisme pelayanan sibuk, dapat dikatakan bahwa sistem antrian sedang dalam periode sibuk. Peluang bahwa sistem antrian sedang dalam keadaan sibuk pada saat sekarang, dinamakan peluang periode sibuk.

Peluang periode sibuk dari sistem antrian dengan pelayanan tunggal sama dengan intensitas lalu - lintas. Karena itu, bila $f(b)$ merupakan fungsi peluang periode sibuk, maka :

$f(b)=\rho=\frac{\lambda}{\mu}$

\section{Distribusi Peluang dari Langganan dalam sistem}

Bila $\rho$ merupakan peluang bahwa system antrian adalah sibuk, maka tentu 1 $\rho$ merupakan peluang bahwa system tidak dalam keadaaan sibuk pada sebarang waktu. Artinya 1- $\rho$ merupakan peluang adanya $n$ langganan. Misalnya $\mathrm{P} n$ merupakan peluang adanya $n$ langganan dalam antrian,

maka untuk $\mathrm{n}=0: \mathrm{P} n=1-\rho$

Karena $\mathrm{P} n=\rho_{\mathrm{n}}$. Pn, maka :

$\mathrm{P} n=\rho$ n $(1-\rho)$

diketahui :

$\mathrm{P} n=$ Peluang dalam $\mathrm{n}$ langganan

$\rho_{n}=$ Peluang system antrian sibuk dalam $n$ langganan

\section{Jumlah rata-rata dalam Sistem}

Misalkan $L s$ berupa jumlah rata - rata langganan dalam sistem antrian, mencakup 
langganan yang menunggu dan yang sedang dilayani.

$$
L s=\frac{\lambda^{2}}{\mu-\lambda}
$$

5. Rata-Rata jumlah pelanggan dalam baris antrian

$$
L q=\frac{\lambda^{2}}{\mu(\mu-\lambda)}
$$

6. Jumlah Rata-Rata yang Menerima Layanan

Misalkan $E\left(n_{s}\right)$ adalah jumlah rata rata yang menerima layanan, jadi :

$\mathrm{E}\left(\mathrm{n}_{\mathrm{s}}\right)=\mathrm{E}\left(\mathrm{n}_{\mathrm{t}}\right)-\mathrm{E}\left(\mathrm{n}_{\mathrm{w} /}\right)=$

$$
\frac{\rho}{1-\rho}-\frac{\rho^{2}}{1-\rho}=\rho
$$

\section{Waktu rata - rata dalam system antrian}

Wt merupakan waktu rata - rata yang dihabiskan oleh seorang pelanggan dalam antrian.

$W_{s}=\frac{1}{\mu-\lambda}$

\section{Waktu Rata - Rata menunggu dalam antrian}

Waktu rata-rata yang dihabiskan seorang pelanggan untuk menunggu dalam antrian sampai dilayani

$$
W q=\frac{\lambda^{2}}{\mu(\mu-\lambda)}
$$

\section{HASIL DAN PEMBAHASAN}

\section{Analisa Sistem Yang Sedang Berjalan}

Analisa sistem yang sedang berjalan dapat diartikan sebagai suatu kegiatan untuk memperoleh gambaran mengenai keadaan sistem yang sedang berjalan. Di Bank Mega Padang pada sistem antrian teller yang menangani transaksi nasabah, analisis sistemnya adalah pada penganalisisan kondisi data-data jadwal antrian antrian nasabah yang telah diperoleh dari teller counter bank Mega Padang, yang salah satu tujuannya adalah untuk menentukan penjadwalan antrian nasabah pada transaksi teller, waktu dan status teller yang menganggur dan tidak menganggur, tergantung pada lama transaksi nasabah dilayani oleh teller bank. Penilaian hasil kesimpulan akhir yang dilakukan berdasarkan atas 3 (tiga) variabel penilaian yaitu dilihat dari nasabah, waktu kedatangan dan waktu mulai dilayani . Contoh laporan yang ada pada saat ini adalah seperti diperlihatkan pada Tabel 1.

Tabel 1. Laporan penjadwalan antrian nasabah

\begin{tabular}{cc}
\hline $\begin{array}{c}\text { Nasabah } \\
\text { Ke }\end{array}$ & $\begin{array}{c}\text { Waktu Kedatangan } \\
\text { di Teller }\end{array}$ \\
\hline 1 & $8: 00: 00$ \\
2 & $8: 01: 00$ \\
3 & $8: 01: 02$ \\
4 & $8: 04: 10$ \\
5 & $8: 06: 25$ \\
6 & $8: 08: 13$ \\
7 & $8: 10: 23$ \\
8 & $8: 12: 14$ \\
9 & $8: 14: 30$ \\
\hline
\end{tabular}

Dari bentuk laporan diatas penjadwalan antrian nasabah yang tepat dan sulit didapatkan, karena tidak lengkapnya bentuk laporan yang diberikan, dan tidak ada variabel-variabel yang mendukung dalam pembuatan model dan simulasi. Seperti contohnya pada kolom waktu 
dilayani, nasabah hanya dinyatakan waktu kedatangan, tanpa dirinci secara jelas berapa mulai dilayani, waktu tunggu, lama pelayanan dan waktu di bank, sehingga tidak diketahui waktu teller yang menganggur sulit ditentukan.

\section{a.Rancangan model dan simulasi}

Teknik simulasi merupakan salah satu cara yang lebih baik dalam memecahkan masalah antrian dengan ditribusi waktu kedatangan dan waktu pelayanan yang random. Simulasi dapat menirukan semirip mungkin keadaan yang sebenarnya terjadi dalam sistem antrian. Berdasarkan analisis data menggunakan metode simulasi, diperoleh hasil penelitian dan pembahasan.

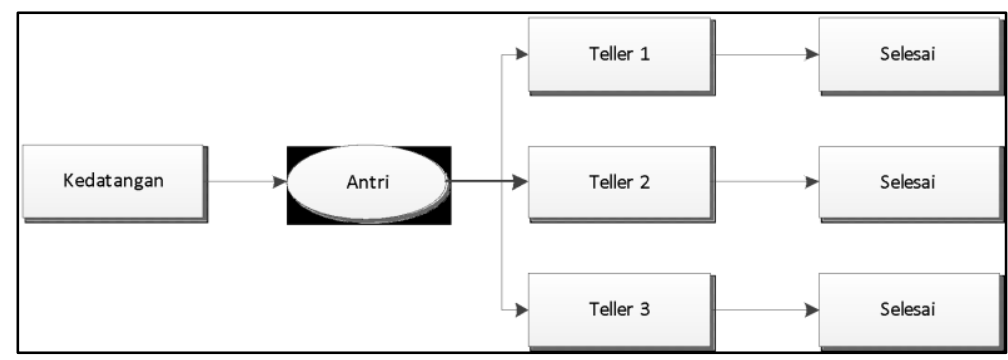

Gambar 7. Sistem Antrian di Bank Mega Padang

Secara umum sistem antrian pada transaksi teller di Bank Mega padang dapat dijelaskan sebagai berikut.

1. Mempunyai 3 teller, karena terdapat 3 counter yang melayani transaksi nasabah.

2. Kapasitas antriannya tak terbatas.

3. Sistem antriannya menggunakan disiplin antrian FIFO (first in first out).

4. Nasabah yang datang mulai diperhitungkan waktu kedatangan nasabah ( nasabah masuk ke sistem antrian ).

5. Setelah nasabah memasuki ruang antrian, nasabah membentuk suatu antrian atau baris tunggu. Nasabah menunggu sampai teller memanggil untuk melakukan transaksi di teller. Tahap ini merupakan waktu yang diperhitungkan sebagai waktu tunggu nasabah di dalam sistem.

6. Tahap selanjutnya adalah proses transaksi. Pada tahap ini dicatat waktu yang dibutuhkan seorang teller dalam melayani setiap nasabah.

7. Setelah proses transaksi selesai, nasabah meninggalkan bank. Berdasarkan pengamatan yang telah dilakukan sistem antrian pada transaksi teller di Bank Mega Padang dapat dilihat pada

b. Diagram Alir Model Simulasi

Diagram alir model simulasi ditunjukkan pada Gambar 8

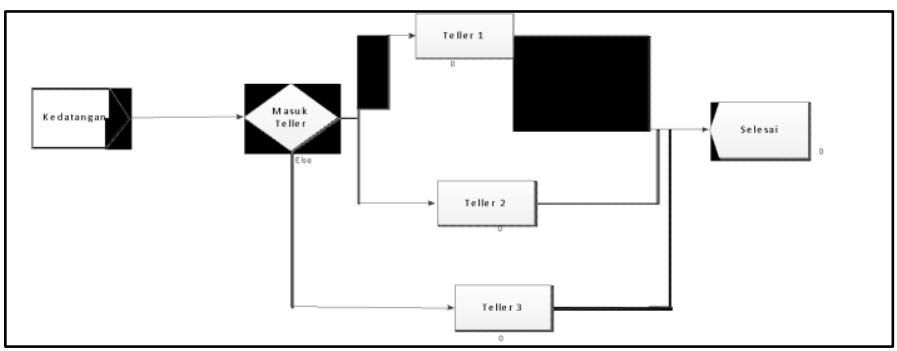

Gambar 8. Diagram Alir Model Simulasi 
Firdalius, F. 2017. Penerapan Model Simulasi Penjadwalan Antrian pada Nasabah Bank Mega Padang. Journal of Sainstek 9(2): 168-182

Berdasarkan Diagram alir model simulasi antrian teller didapatkan :

1. Prosedur model simulasi antrian

a. Langkah pertama dalam pembuatan simulasi model antrian ini digunakan modul create. Modul ini digunakan sebagai titik awal masuknya entitas dalam model simulasi. Entitas dalam model simulasi ini adalah pelanggan yang akan bertransaksi. Atribut dalam modul create ini sebagai berikut:Name : Kedatangan,Entity Type : Customer

b. Langkah kedua digunakan modul decide, modul ini mempertimbangkan keputusan yang akan diambil dalam sistem. c. Langkah ketiga digunakan modul process, di dalam modul ini terjadi proses utama dalam simulasi. Process dalam model simulasi ini ada 3, karena banyaknya pelayan dalam sistem terdiri dari 3 counter.

d. Langkah terakhir digunakan modul dispose, modul ini digunakan sebagai titik akhir entitas dalam model simulasi. Atribut dalam modul dispose ini sebagai berikut :Name : Selesai,Record Entity Statistics : Yes

Data banyak nasabah dan waktu kedatangan dapat dilihat pada Table 2 sebagai berikut :

Tabel 2 Kedatangan Nasabah di Bank

\begin{tabular}{|c|c|c|c|c|}
\hline Nasabah & Waktu Kedatangan & \multicolumn{3}{|c|}{ Waktu Mulai Dilayani } \\
\hline Ke & di Teller & Teller 1 & Teller 2 & Teller 3 \\
\hline 1 & $8: 00: 00$ & 8:00:00 & O:O0:00 & 0:00:00 \\
\hline 2 & 8:01:00 & $0: 00: 00$ & O:00:00 & 8:01:00 \\
\hline 3 & 8:01:02 & $0: 00: 00$ & 8:01:02 & $0: 00: 00$ \\
\hline 4 & $8: 04: 10$ & $0: 00: 00$ & $8: 04: 10$ & $0: 00: 00$ \\
\hline 5 & $8: 06: 25$ & $8: 08: 10$ & $0: 00: 00$ & $0: 00: 00$ \\
\hline 6 & $8: 08: 13$ & $0: 00: 00$ & $0: 00: 00$ & $8: 09: 17$ \\
\hline 7 & $8: 10: 23$ & $8: 11: 00$ & $0: 00: 00$ & $0: 00: 00$ \\
\hline 8 & $8: 12: 14$ & $0: 00: 00$ & $8: 13: 53$ & $0: 00: 00$ \\
\hline 9 & $8: 14: 30$ & $8: 15: 29$ & $0: 00: 00$ & $0: 00: 00$ \\
\hline 10 & $8: 16: 26$ & $0: 00: 00$ & $0: 00: 00$ & $8: 17: 30$ \\
\hline 11 & $8: 18: 20$ & $8: 19: 28$ & $0: 00: 00$ & $0: 00: 00$ \\
\hline 12 & $8: 20: 18$ & $0: 00: 00$ & $8: 21: 37$ & $0: 00: 00$ \\
\hline 13 & $8: 22: 29$ & $8: 23: 09$ & $0: 00: 00$ & $0: 00: 00$ \\
\hline 14 & $8: 24: 13$ & $0: 00: 00$ & $0: 00: 00$ & $8: 25: 56$ \\
\hline 15 & $8: 25: 57$ & $0: 00: 00$ & $8: 26: 34$ & $0: 00: 00$ \\
\hline 16 & $8: 27: 41$ & $0: 00: 00$ & $0: 00: 00$ & $8: 28: 21$ \\
\hline 17 & $8: 29: 25$ & $0: 00: 00$ & $8: 30: 01$ & $0: 00: 00$ \\
\hline 18 & $8: 31: 09$ & $8: 32: 46$ & O:00:00 & $0: 00: 00$ \\
\hline 19 & $8: 33: 03$ & O:00:00 & O:00:00 & $8: 34: 35$ \\
\hline 20 & $8: 35: 57$ & $8: 36: 40$ & O:00:00 & $0: 00: 00$ \\
\hline 21 & $8: 37: 51$ & O:00:00 & $8: 38: 02$ & $0: 00: 00$ \\
\hline 22 & $8: 39: 45$ & $0: 00: 00$ & O:00:00 & $8: 40: 33$ \\
\hline 23 & $8: 41: 39$ & $0: 00: 00$ & 8:42:04 & $0: 00: 00$ \\
\hline 24 & $8: 43: 33$ & $0: 00: 00$ & $0: 00: 00$ & $8: 44: 42$ \\
\hline 25 & 8:45:00 & $8: 46: 45$ & $0: 00: 00$ & $0: 00: 00$ \\
\hline 26 & $8: 46: 27$ & $0: 00: 00$ & $8: 47: 24$ & $0: 00: 00$ \\
\hline 27 & $8: 47: 54$ & $8: 48: 09$ & O:00:00 & $0: 00: 00$ \\
\hline 28 & $8: 49: 21$ & O:00:00 & $8: 50: 32$ & $0: 00: 00$ \\
\hline 29 & $8: 51: 48$ & O:00:00 & O:00:00 & $8: 52: 07$ \\
\hline 30 & $8: 53: 15$ & O:O0:00 & $8: 54: 09$ & $0: 00: 00$ \\
\hline 31 & $8: 55: 42$ & $8: 56: 37$ & O:OO:OO & $0: 00: 00$ \\
\hline 32 & $8: 57: 09$ & O:OO:OO & O:OO:OO & 8:58:11 \\
\hline 33 & $8: 59: 36$ & O:00:00 & 9:00:43 & $0: 00: 00$ \\
\hline 34 & 9:01:03 & O:00:00 & O:00:00 & 9:02:04 \\
\hline 35 & $9: 03: 30$ & $9: 04: 43$ & O:00:00 & $0: 00: 00$ \\
\hline 36 & 9:05:57 & O:00:00 & 0:00:00 & 9:06:55 \\
\hline 37 & 9:07:24 & O:00:00 & 9:09:43 & 0:00:00 \\
\hline 38 & 9:09:51 & O:00:00 & O:00:00 & $9: 10: 13$ \\
\hline 39 & $9: 11: 18$ & $9: 12: 53$ & O:00:00 & $0: 00: 00$ \\
\hline 40 & $9: 13: 45$ & O:00:00 & O:00:00 & 9:14:22 \\
\hline 41 & $9: 15: 12$ & O:00:00 & $9: 16: 55$ & $0: 00: 00$ \\
\hline 42 & $9: 17: 39$ & 9:18:03 & O:00:00 & $0: 00: 00$ \\
\hline 43 & 9:19:06 & O:00:00 & 9:20:33 & 0:00:00 \\
\hline 44 & 9:21:15 & 9:22:40 & O:00:00 & $0: 00: 00$ \\
\hline 45 & $9: 23: 42$ & O:00:00 & O:00:00 & 9:24:06 \\
\hline 46 & 9:25:09 & 9:26:41 & O:00:00 & 0:00:00 \\
\hline 47 & 9:27:36 & O:00:00 & O:00:00 & $9: 27: 45$ \\
\hline 48 & 9:29:03 & $9: 30: 23$ & O:00:00 & 0:00:00 \\
\hline 49 & 9:31:30 & O:00:00 & 9:32:05 & O:00:00 \\
\hline 50 & 9:33:57 & o:00:00 & O:00:00 & 9:34:23 \\
\hline 51 & $9: 35: 24$ & 0:00:00 & 9:37:44 & O:00:00 \\
\hline 52 & $9: 37: 51$ & 9:38:22 & 0:00:00 & O:00:00 \\
\hline 53 & 9:39:18 & O:OO:00 & 0:00:00 & $9: 40: 53$ \\
\hline$\frac{54}{55}$ & $\begin{array}{l}9: 40: 45 \\
9: 42: 12\end{array}$ & $\frac{0: 00: 00}{0: 00: 00}$ & $\frac{9: 42: 25}{0.00: 00}$ & $\begin{array}{l}0: 0: 0000 \\
9: 44: 20\end{array}$ \\
\hline 56 & $9: 43: 39$ & 9:45:05 & $0: 00: 00$ & $0: 00: 00$ \\
\hline 57 & $9: 45: 06$ & O:OO:OO & O:OO:OO & 9:46:00 \\
\hline 58 & $9: 46: 33$ & $0: 00: 00$ & 9:48:43 & $0: 00: 00$ \\
\hline 59 & 9:48:00 & O:OO:OO & O:OO:OO & $9: 50: 31$ \\
\hline 60 & $9: 49: 27$ & $9: 50: 30$ & $0: 00: 00$ & $0: 00: 00$ \\
\hline 61 & 9:50:54 & O:00:00 & 9:51:45 & $0: 00: 00$ \\
\hline 62 & $9: 52: 21$ & O:O0:00 & O:OO:OO & 9:52:50 \\
\hline 63 & 9:53:48 & $9: 54: 58$ & O:OO:OO & O:00:00 \\
\hline 64 & 9:55:15 & $0: 00: 00$ & $0: 00: 00$ & $9: 57: 30$ \\
\hline 65 & 9:56:42 & $0: 00: 00$ & $9: 58: 36$ & $0: 00: 00$ \\
\hline
\end{tabular}


Tabel 2 memperlihatkan data nasabah dan waktu kedatangan nasabah di bank, dalam table waktu kedatangan nasabah ini hanya terdiri dari dua bagian yaitu : adanya nasabah ke ( Arrival no ) orang nasabah yang datang dan waktu kedatangan $(\mathrm{t})$ yang berbeda.

Diketahui pada suatu percobaan simulasi dari suatu sistem proses antrean distribusi kedatangan adalah distribusi eksponential dengan rata - rata waktu antar kedatangan $($ IAT $)=60$ detik. Dengan cara simulasi melalui distribusi ini telah diperoleh data dari 65 unit / person kedatangan (arrival number ).

Waktu Pelayanan Nasabah (t)

Dijelaskan juga waktu pelayanan teller terhadap nasabah Bank Mega Padang yang terdiri dari 3 counter yang ada.

(t) merupakan hasil dari simulasi untuk arrival yang diambil dari bank Mega Padang :

$\mathrm{t} 1=08: 00: 00, \mathrm{t} 2=08: 01: 00, \mathrm{t} 3=$ 08:01:02 ... Dan seterusnya sampai t65 $=$ 09:55:42.

Pengambilan data dilakukan di setiap counter, jadi waktu yang dicatat adalah waktu yang dibutuhkan seorang teller untuk melayani seorang nasabah pada setiap counter yang ada. Waktu pelayanan nasabah dikategorikan sebagai berikut :

a. Waktu pelayanan (ST) di teller 1

b. Waktu pelayanan (ST) di teller 2

c. Waktu pelayanan (ST) di teller 3

\section{Sistem Antrian Bank Mega Padang}

Dalam melayani transaksi di bagian

teller, Bank Mega menggunakan struktur model antrian multi channel - single phase, artinya terdapat lebih dari satu teller (layanan) yang disediakan untuk melayani para nasabah dan hanya satu tahap pelayanan (phase) yang harus dilalui oleh nasabah untuk menyelesaikan transaksi.

Adapun jumlah fasilitas pelayanan yang disediakan adalah sebanyak 3 teller, para nasabah yang akan melakukan transaksi harus menunggu dalam jalur antrian sebelum mereka dilayani.

Waktu yang dibutuhkan oleh setiap teller untuk melayani nasabah yang satu dengan yang lainnya bersifat random / acak. Lamanya waktu pelayanan tergantung pada jenis transaksi maupun besarnya transaksi yang dilakukan oleh nasabah.

Prosedur pelayanan yang dilakukan oleh setiap teller dalam melayani transaksi untuk nasabah adalah sebagai berikut:

1. Memeriksa kebenaran dan kelengkapan pengisian data pada slip transaksi untuk menghindari terjadinya kesalahan,

2. Memeriksa specimen nasabah, kecuali untuk warkat bank lain,

3. Meminta atau menginformasikan sesuatu pada nasabah sehubungan dengan transaksi yang dilakukan (terutama dalam transaksi penarikan), seperti :

- Meminta nasabah menunggu karena transaksi antar cabang yang memerlukan waktu cukup lama untuk memprosesnya. Bila perlu meminta nasabah untuk menunggu dikursi tamu untuk mengantri dan kemudian akan dipanggil kembali.

4. Menerima setoran dan melakukan pembayaran serta memeriksa keabsahan fisik uang.

5. Menghitung uang dihadapan nasabah, melihat perhitungan yang dilakukan teller, baik menggunakan mesin maupun manual.

6. Mengesahkan transaksi dengan cara memposting serta memeriksa hasil validasinya atau membubuhkan time stam dan paraf

7. Mengkonfirmasikan nominal uang untuk semua transaksi

8. Meneruskan dokumen yang harus diproses lebih lanjut.

\section{Tujuan Bank Mega Menyediakan Fasilitas Sistem Antrian}

Adapun tujuan-tujuan dari Bank Mega menyediakan fasilitas sistem antrian, antara lain adalah untuk:

1. Melayani nasabah yang membutuhkan pelayanan dengan tertib dan teratur .

2. Melayani nasabah dengan nyaman .

3. Mendidik nasabah agar berdisiplin dan beretika dengan baik.

Faktor-faktor yang dipertimbangkan oleh Bank Mega dalam menentukan Model dan Sistem Antrian

1. Kenyamanan nasabah dalam sistem antrian 
2. Kelancaran proses pelayanan nasabah dalam sistem antrian

3. Waktu tunggu nasabah dalam sistem antrian

4. Keterlibatan nasabah dalam sistem antrian

\section{Kinerja Sistem Antrian}

Kinerja sistem antrian meliputi perhitungan sebagai berikut :

(a) Nasabah ke (Arrival no) $=1,2,3,4,5$, ...dan seterusnya sampai 65 .

(b) Waktu antar kedatangan (Inter Arrival Time ) $\mathrm{t} 1=08: 00: 00, \mathrm{t} 2=08: 01: 00, \mathrm{t} 3=08: 01: 02$ .... Dan seterusnya sampai t65 $=09: 55: 42$.

(c) Arrival time atau waktu kedatangan yang merupakan penjumlahan dari inter arrival time untuk waktu antar kedatangan untuk setiap kedatangan.Berarti 08:00:00 08:01:00 08:01:02 Untuk 65 kedatangan

(d) Service time, yaitu waktu pelayanan dengan distribusi eksponensial dengan rata rata / menit.

Tingkat kedatangan nasabah adalah banyaknya nasabah yang datang untuk mendapatkan pelayanan dari teller, dinyatakan dalam berapa banyak nasabah (orang) yang datang dalam periode waktu tertentu. Tingkat kedatangan nasabah diasumsikan mengikuti distribusi poison, yaitu distribusi probabilitas untuk menghitung jumlah kedatangan suatu periode tertentu dari sebuah proses poison. Proses poison sendiri adalah kedatangan nasabah lain, juga tidak tergantung pada waktu (tidak terbatas).

Sedangkan tingkat pelayanan teller adalah lamanya waktu pelayanan yang disediakan oleh teller kepada nasabah, dinyatakan dalam satu satuan waktu (menit). Tingkat pelayanan teller dinyatakan dalam distribusi eksponensial, yaitu distribusi kontinue yang menyatakan semua peluang terjadinya kegagalan pada suatu waktu tertentu.

Sedangkan rata-rata tingkat pelayanan teller untuk setiap periode waktu dapat dilihat dalam hitungan berikut :

Lama pelayanan teller $($ service time $)=$ waktu keluar nasabah - waktu pelayanan. Diketahui arrival no $=65$ unit / orang.
Arrival no $1=8: 02: 45-8: 00: 00=0: 02: 45$

Arrival no $2=8: 02: 40-8: 01: 00=0: 01: 40$

Arrival no $3=8: 04: 05-8: 01: 02=0: 03: 03$

Arrival no $4=8: 06: 20-8: 04: 10=0: 02: 10$

Arrival no $5=8: 10: 13-8: 08: 10=0: 02: 03$

Arrival no $6=8: 13: 50-8: 11: 00=0: 02: 50$

Arrival no $7=8: 13: 50-8: 11: 00=0: 02: 50$

Dan seterusnya,..

Sampai Arrival no $65=10: 58: 58-9: 58: 36=$ 1:00:22

Jadi lama pelayanan teller bank mega dengan 65 unit/ orang $=3: 34: 41$

Rata - rata pelayanan teller $($ service time $)=$ lama pelayanan / 65 unit (orang).

Rata - rata pelayanan teller (service time) $=$ $3: 34: 41 / 65=0: 03: 18$

(e) Intro time, yaitu waktu memasuki fasilitas service dari n kedatangan, dengan kata lain waktu dari unit atau orang yang dating ke $n$ pada service point ( fasilitas service ).

Dengan menggunakan persamaan yang digunakan untuk model multiple channel exponential service time dan dari rata-rata waktu kedatangan dan rata-rata waktu tingkat) maka dapat dihitung kinerja sistem antrian pada Bank Mega.

Sedangkan rata-rata waktu tunggu nasabah dilayani teller untuk setiap periode waktu dapat dijelaskan sebagai berikut :

Into time plus (+) service time atau dapat juga untuk " From time " bagi unit atau orang pada $n-1$.

Arrival no. $1=8: 00: 00-8: 00: 00=0: 00: 00$

Arrival no. $2=8: 01: 00-8: 01: 00=0: 00: 00$

Arrival no. $3=8: 01: 02-8: 01: 02=0: 00: 00$

Arrival no. $4=8: 04: 10-8: 04: 10=0: 00: 00$

Arrival no. $5=8: 08: 10-8: 06: 25=0: 01: 45$

Arrival no. $6=8: 09: 17-8: 08: 13=0: 01: 04$

Arrival no. $7=8: 11: 00-8: 10: 23=0: 00: 37$

Dan seterusnya...

(f) from time ini berarti waktu meninggalkan fasilitas service ( tepat pelayanan ) dari sebanyak $\mathrm{n}$ kedatangan yang dapat memasuki fasilitas service.

Banyaknya waktu meninggalkan fasilitas service ini diperoleh dari :

Into time + service time $=$ From time $($ waktu $)$ meninggalkan sistem antrean. 
Arrival no. $1=$ diperoleh dari 8:00:00 + 0:02:45 $=8: 02: 45$

Arrival No. $2=8: 01: 00+0: 01: 40=8: 02: 40$

Arrival no. $3=8: 01: 02+0: 03: 03=8: 04: 05$

Arrival no. $4=8: 04: 10+0: 02: 10=8: 06: 20$

Arrival no. $5=8: 06: 25+0: 02: 03=8: 10: 13$

Dan seterusnya.

(g) Queueing time. Hal ini merupakan banyaknya waktu antrean, banyaknya waktu bagi unit / person yang berdatangan dalam antrean sebelum memasuki fasilitas service atau yang sudah dicatat dengan Into time.

$($ Into Time $)-($ Arrival Time $)=$ Query time ( waktu dalam antrian)

Pada data ini terdapat jumlah dari waktu antrean sebanyak $=$ 1:09:08 / jam. Ini berarti total waktu hanya dalam antrean atau Queueing Time

adalah $\sum_{i=1}^{n=65}(Q . T)=1: 09: 08 / \mathrm{jam}$

(h) Average Queueing Time $=$ Rata - rata waktu.

- Antrean yang diperoleh dari :

Total Queueing Time dibagi 65 unit $/$ person $=$ 0:01:04 menit.

Sehingga :

$\mathrm{AQT}=$ 1:09:08 / 65 = 0:01:04 menit.
Kinerja sistem antrian Bank Mega setiap tingkat kedatangan dengan tingkat pelayanan tertentu dengan jumalh teller sebanyak 3 (tiga) orang.

\section{Implementasi dan Pengujian}

Teknik simulasi merupakan salah satu cara yang lebih baik dalam memecahkan masalah antrian dengan ditribusi waktu kedatangan dan waktu pelayanan yang random. Simulasi dapat menirukan semirip mungkin keadaan yang sebenarnya terjadi dalam sistem antrian. Berdasarkan analisis data menggunakan metode simulasi, diperoleh hasil penelitian dan pembahasan sebagai berikut:

Arrival time ( waktu kedatangan ) nasabah Bank Mega

Waktu Antar Kedatangan pengambilan data dilakukan dengan mengelompokkan banyaknya nasabah yang datang ke dalam kelas interval. Pengelompokkan ini didasarkan dari observasi yang telah dilakukan sebelumnya, yang bertujuan agar tidak terjadi penumpukkan yang terlalu besar dalam antrian. Data banyak nasabah dan waktu kedatangan dapat dilihat sebagai berikut :

Data banyak nasabah dan waktu kedatangan dapat dilihat pada Gambar 9 sebagai berikut :

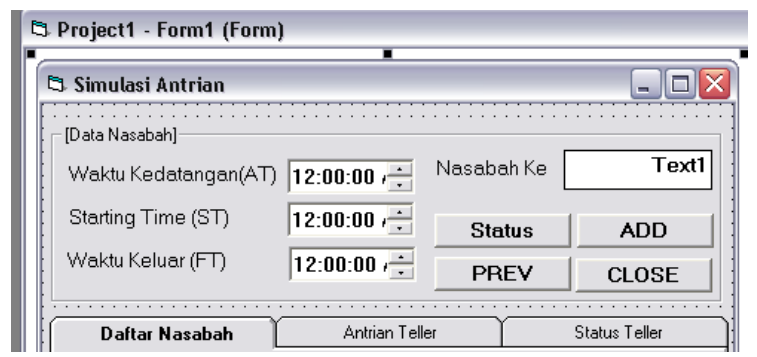

Gambar 9. Entry Kedatangan Nasabah di Bank

Gambar 9 memperlihatkan data nasabah dan waktu kedatangan nasabah di bank, dalam table waktu kedatangan nasabah ini hanya terdiri dari dua bagian yaitu : adanya nasabah ke ( Arrival no ) orang nasabah yang datang dan waktu kedatangan $(t)$ yang berbeda.

\section{Implementasi model simulasi antrian nasabah bank Mega Padang}

Simulasi antrian dapat dilakukan untuk mempermudah pelaksanaan dan juga agar dapat dianalisis dengan cermat. Pada suatu simulasi dari suatu sistem proses antrian diketahui distribusi kedatangan adalah distribusi eksponential dengan rata waktu kedatangan $(\mathrm{IAT})=60$ detik. Dengan cara simulasi melalui distribusi ini telah diperoleh data dari 65 unit / person kedatangan ( arrival number ) . 
Firdalius, F. 2017. Penerapan Model Simulasi Penjadwalan Antrian pada Nasabah Bank Mega Padang. Journal of Sainstek 9(2): 168-182

Model simulasi waktu tunggu nasabah

Pada transaksi nasabah terhadap teller memiliki waktu tunggu nasabah sebelum pelayanan transaksi nasabah pada teller bank Mega Padang. Pada waktu lama pelayanan nasabah dapat dilihat pada Gambar 10 sebagai berikut:

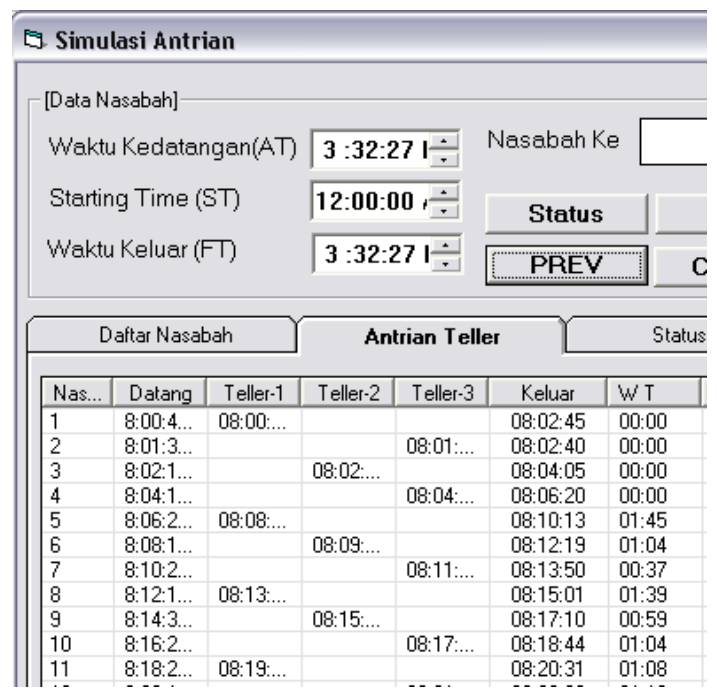

Gambar 10. Waktu tunggu nasabah

Pada Gambar 10 waktu tunggu nasabah di atas diketahui waktu mulai pelayanan nasabah dikurangi waktu kedatangan nasabah di bank.

\section{Model waktu pelayanan nasabah}

Model pelayanan nasabah dalam antrian untuk manajemen mengetahui lamanya waktu pelayanan transaksi nasabah pada teller bank Mega Padang. Pada waktu lama pelayanan nasabah dapat dilihat pada Gambar 11 sebagai berikut :

\begin{tabular}{|c|c|c|c|c|c|c|c|}
\hline \multicolumn{7}{|c|}{ Simulasi Antrian } & - \\
\hline \multicolumn{8}{|c|}{ [Data Nasabah] ${ }^{-}$} \\
\hline \multicolumn{3}{|c|}{ Waktu Kedatangan(AT) } & \multicolumn{2}{|c|}{$3: 32: 271 \div$} & \multicolumn{2}{|c|}{ Nasabah Ke } & \\
\hline \multicolumn{3}{|c|}{ Starting Time (ST) } & \multicolumn{2}{|c|}{ 12:00:00 $\div$} & \multicolumn{2}{|l|}{ Status } & ADD \\
\hline \multicolumn{3}{|c|}{ Waktu Keluar (FT) } & \multicolumn{2}{|c|}{$3: 32: 271 \div$} & \multicolumn{2}{|l|}{ PREV } & CLOSE \\
\hline \multicolumn{3}{|c|}{ Daftar Nasabah } & \multicolumn{3}{|c|}{ Antrian Teller } & \multicolumn{2}{|c|}{ Status Teller } \\
\hline Nas... & Datang & Teller- 1 & Teller-2 & Teller-3 & Keluar & WT & LP \\
\hline 1 & $8: 00: 4 \ldots$ & $08: 00: \ldots$ & & & $08: 02: 45$ & $00: 00$ & $02: 02$ \\
\hline 2 & $8: 01: 3 \ldots$ & & & 08:01:... & 08:02:40 & 00:00 & $01: 06$ \\
\hline 3 & $8: 02: 1 \ldots$ & & $08: 02 \ldots$ & & $08: 04: 05$ & $00: 00$ & $01: 54$ \\
\hline 4 & $8: 04: 1 \ldots$ & & & $08: 04 \ldots$ & $08: 06: 20$ & $00: 00$ & $02: 10$ \\
\hline 5 & $8: 06: 2 \ldots$ & 08:08:... & & & 08:10:13 & $01: 45$ & $02: 03$ \\
\hline 6 & $8: 08: 1 \ldots$ & & $08: 09: \ldots$ & & $08: 12: 19$ & $01: 04$ & $03: 02$ \\
\hline 7 & $8: 10: 2 \ldots$ & & & $08: 11 \ldots$ & $08: 13: 50$ & $00: 37$ & $02: 50$ \\
\hline 8 & $8: 12: 1 \ldots$ & $08: 13 \ldots$ & & & $08: 15: 01$ & $01: 39$ & $01: 08$ \\
\hline 9 & $8: 14: 3 \ldots$ & & $08: 15 \ldots$ & & $08: 17: 10$ & $00: 59$ & $01: 41$ \\
\hline 10 & $8: 16: 2 \ldots$ & & & $08: 17 \ldots$ & $08: 18: 44$ & 01:04 & $01: 14$ \\
\hline 11 & $8: 18: 2 \ldots$ & $08: 19: \ldots$ & & & $08: 20: 31$ & $01: 08$ & $01: 03$ \\
\hline 12 & $8: 20: 1 \ldots$ & & & $08: 21: \ldots$ & $08: 23: 00$ & $01: 19$ & $01: 23$ \\
\hline
\end{tabular}

Gambar 11. Waktu pelayanan nasabah pada teller 
Waktu yang dibutuhkan oleh setiap teller untuk melayani nasabah yang satu dengan yang lainnya bersifat random / acak. Lamanya waktu pelayanan tergantung pada jenis transaksi maupun besarnya transaksi yang dilakukan oleh nasabah. Perhitungan waktu pelayanan nasabah yaitu waktu keluar dikurangi waktu mulai dilayani nasabah pada teller.

\section{Model waktu pelayanan nasabah di bank}

Dalam model antrian nasabah juga diketahui waktu nasabah dibank untuk mengetahui sistem antrian yang ada dalam bank. Perhitungan waktu nasabah di bank yaitu lama pelayanan ditambah waktu tunggu nasabah. Waktu nasabah dibank dapat dilihat pada Gambar 12 sebagai berikut :

\begin{tabular}{|c|c|c|c|c|c|c|c|}
\hline \multicolumn{6}{|c|}{ Simulasi Antrian } & & $=$ \\
\hline \multicolumn{8}{|c|}{-[Data Nasabah] } \\
\hline \multicolumn{3}{|c|}{ Waktu Kedatangan(AT) } & $3: 32: 271 \div$ & \multicolumn{2}{|c|}{ Nasabah Ke } & \multicolumn{2}{|r|}{17} \\
\hline \multicolumn{2}{|c|}{ Starting Time (ST) } & \multicolumn{2}{|c|}{ 12:00:00 : } & \multicolumn{2}{|c|}{ Status } & \multicolumn{2}{|c|}{ ADD } \\
\hline \multicolumn{2}{|c|}{ Waktu Keluar (FT) } & \multicolumn{2}{|c|}{$3: 32: 271 \div$} & \multicolumn{2}{|c|}{ PREV } & \multicolumn{2}{|c|}{ CLOSE } \\
\hline \multicolumn{2}{|c|}{ Daftar Nasabah } & \multicolumn{3}{|c|}{ Antrian Teller } & \multicolumn{3}{|c|}{ Status Teller } \\
\hline Datang & Teller -1 & Teller-2 & Teller-3 & Keluar & WT & LP & DiBank \\
\hline $8: 00: 4 \ldots$ & $08: 00 \ldots$ & & & 08:02:45 & $00: 00$ & $02: 02$ & 02:02 \\
\hline $8: 01: 3 \ldots$ & & & $08: 01 \ldots$ & 08:02:40 & 00:00 & $01: 06$ & 01:06 \\
\hline $8: 02: 1 \ldots$ & & $08: 02 \ldots$ & & 08:04:05 & 00:00 & $01: 54$ & $01: 54$ \\
\hline $8: 04: 1 \ldots$ & & & $08: 04 \ldots$ & 08:06:20 & 00:00 & 02:10 & 02:10 \\
\hline $8: 06: 2 \ldots$ & 08:08... & & & 08:10:13 & $01: 45$ & 02:03 & 03:48 \\
\hline $8: 08: 1 \ldots$ & & 08:09:... & & $08: 12: 19$ & 01:04 & 03:02 & 04:06 \\
\hline $8: 10: 2 \ldots$ & & & $08: 11 \ldots$ & 08:13:50 & $00: 37$ & $02: 50$ & $03: 27$ \\
\hline $8: 12: 1 \ldots$ & 08:13: & & & $08: 15: 01$ & 01:39 & $01: 08$ & $02: 47$ \\
\hline $8: 14: 3 \ldots$ & & $08: 15 \ldots$ & & $08: 17: 10$ & $00: 59$ & $01: 41$ & $02: 40$ \\
\hline $8: 16: 2 \ldots$ & & & $08: 17 \ldots$ & $08: 18: 44$ & 01:04 & $01: 14$ & $02: 18$ \\
\hline $8: 18: 2 \ldots$ & $08: 19 \ldots$ & & & $08: 20: 31$ & 01:08 & 01:03 & 02:11 \\
\hline $8: 20: 1 \ldots$ & & & $08: 21 \ldots$ & $08: 23: 00$ & $01: 19$ & $01: 23$ & $02: 42$ \\
\hline $8: 22: 2 \ldots$ & $08: 23 \ldots$ & & & $08: 25: 11$ & $00: 40$ & $02: 02$ & $02: 42$ \\
\hline $8: 24: 1 \ldots$ & & & $08: 25 \ldots$ & $08: 26: 59$ & $01: 43$ & 01:03 & $02: 46$ \\
\hline $8: 25: 5 \ldots$ & & $08: 26 \ldots$ & & $08: 27: 50$ & $00: 37$ & $01: 16$ & 01:53 \\
\hline $8: 27: 4 \ldots$ & $08: 28 \ldots$ & & & $08: 30: 05$ & $00: 40$ & $01: 44$ & $02: 24$ \\
\hline
\end{tabular}

Gambar 12 Waktu nasabah di bank

Dalam model antrian nasabah juga diketahui waktu nasabah dibank untuk mengetahui sistem antrian yang ada dalam bank. Perhitungan waktu nasabah di bank yaitu lama pelayanan ditambah waktu tunggu nasabah.

\section{Pengujian simulasi antrian nasabah pada bank Mega Padang}

Setelah dilakukan analisis terhadap sistem maka dilakukan pengujian terhadap program yang dibuat, dengan tujuan untuk mengetahui apakah sasaran yang diinginkan telah dapat dicapai sesuai dengan yang telah dinyatakan sebelumnya yaitu, setelah dilakukan perancangan model antrian nasabah bank Mega Padang ternyata sistem yang dihasilkan dapat membantu manajemen untuk mengetahui nilai antrian dan status teller. Informasi yang dihasilkan sebelumnya tidak jelas yang selama ini hanya menampilkan kondisi teller sibuk atau menganggur.

Dengan merancang model antrian nasabah ini maka bentuk laporan yang dihasilkan menjadi lebih lengkap dan menghasilkan suatu nilai antrian dan status teller untuk pengambilan keputusan manajemen terhadap transaksi teller, dengan melakukan proses.

Untuk menguji kebenaran dari hasil pengolahan data yang dikerjakan secara manual tersebut, kita dapat menggunakan salah satu software aplikasi visual basic 6.0 dan hasil pengujiannya. Data pengujian dapat dilihat pada Gambar 12 sebagai berikut : 
Firdalius, F. 2017. Penerapan Model Simulasi Penjadwalan Antrian pada Nasabah Bank Mega Padang. Journal of Sainstek 9(2): 168-182

Tabel 3. Nilai antrian pada teller Bank Mega Padang

\begin{tabular}{|c|c|c|c|c|c|c|c|}
\hline \multicolumn{3}{|c|}{ Daftar Nasabah } & \multicolumn{2}{|c|}{ Antrian Teller } & & \multicolumn{2}{|c|}{ Status Teller } \\
\hline $\mathrm{Nas} . \mathrm{Ke}$ & Datang & Teller 1 & Teller-2 & Teller-3 & Keluar & WT & DiBank \\
\hline \begin{tabular}{|l|l|}
1 \\
\end{tabular} & $8: 00: 43 \mathrm{AM}$ & $08: 00: 43$ & & & $08: 02: 45$ & 00:00 & $02: 02$ \\
\hline 2 & 8:01:34 AM & & & 08:01:34 & $08: 02: 40$ & 00:00 & 01:06 \\
\hline 3 & $8: 02: 11 \mathrm{AM}$ & & $08: 02: 11$ & & 08:04:05 & 00:00 & $01: 54$ \\
\hline 4 & 8:04:10 AM & & & 08:04:10 & $08: 06: 20$ & $00: 00$ & $02: 10$ \\
\hline 5 & $8: 06: 25 \mathrm{AM}$ & 08:08:10 & & & $08: 10: 13$ & $01: 45$ & 03.48 \\
\hline 6 & $8: 08: 13 \mathrm{AM}$ & & 08:09:17 & & $08: 12: 19$ & 01:04 & $04: 06$ \\
\hline 7 & $8: 10: 23 \mathrm{AM}$ & & & 08:11:00 & $08: 13: 50$ & 00:37 & $03: 27$ \\
\hline 8 & 8:12:14 AM & 08:13:53 & & & 08:15:01 & $01: 39$ & $02: 47$ \\
\hline 9 & $8: 14: 30 \mathrm{AM}$ & & $08: 15: 29$ & & 08:17:10 & $00: 59$ & $02: 40$ \\
\hline 10 & $8: 16: 26 \mathrm{AM}$ & & & $08: 17: 30$ & $08: 18: 44$ & 01:04 & $02: 18$ \\
\hline 11 & $8: 18: 20 \mathrm{AM}$ & 08:19:28 & & & $08: 20: 31$ & 01:08 & 02:11 \\
\hline 12 & $8: 20: 18 \mathrm{AM}$ & & & $08: 21: 37$ & $08: 23: 00$ & $01: 19$ & $02: 42$ \\
\hline 13 & $8: 22: 29 \mathrm{AM}$ & 08:23:09 & & & $08: 25: 11$ & $00: 40$ & $02: 42$ \\
\hline 14 & $8: 24: 13 \mathrm{AM}$ & & & $08: 25: 56$ & $08: 26: 59$ & $01: 43$ & $02: 46$ \\
\hline 15 & $8: 25: 57 \mathrm{AM}$ & & $08: 26: 34$ & & $08: 27: 50$ & $00: 37$ & $01: 53$ \\
\hline 16 & 8:27:41 AM & $08: 28: 21$ & & & 08:30:05 & $00: 40$ & $02: 24$ \\
\hline 17 & 8:10:48 PM & & $00: 00: 00$ & & 20:10:48 & $10: 48$ & 00:00 \\
\hline
\end{tabular}

Tabel 4. Nilai status pada teller Bank Mega Padang

\begin{tabular}{|c|c|c|c|c|c|c|c|c|}
\hline \multicolumn{3}{|c|}{ Daftar Nasabah } & \multicolumn{3}{|c|}{ Antrian Teller } & \multicolumn{3}{|c|}{ Status Teller } \\
\hline Waktu & Nasab. & Kejadian & Antrian & Jml Nas & Teller-1 & Teller.2 & Teller-3 & 人 \\
\hline $8.00: 43 \mathrm{AM}$ & 1 & Datang & 0 & 1 & Sibuk & Menganggur & Menganggur & \\
\hline 8:01:34.AM & 2 & Datang & 0 & 2 & Sibuk & Menganggur & Sibuk & \\
\hline $\begin{array}{l}8: 02: 11 \mathrm{AM} \\
80.02: 40 \mathrm{AM}\end{array}$ & 3 & $\begin{array}{l}\text { Datang } \\
\text { Keluar }\end{array}$ & 0 & 3 & Sibuk & Sibuk & Sibuk & \\
\hline $\begin{array}{l}8.02: 40 A M \\
8.02 .45 \Delta M\end{array}$ & ${ }_{1}^{2}$ & $\begin{array}{l}\text { Keluar } \\
\text { Keluar }\end{array}$ & $\begin{array}{l}0 \\
0\end{array}$ & 2 & $\begin{array}{l}\text { Sbbuk } \\
\text { Mengangour }\end{array}$ & Menganggur & Menganggur & \\
\hline 8:04:05 AM & 3 & $\begin{array}{l}\text { Keluar } \\
\text { Keluar }\end{array}$ & 0 & 0 & Mengengangugur & Mengangour & Sibuk & \\
\hline 8:04:10 AM & 4 & Datang & 0 & 1 & Menganggur & Menganggur & Sibuk & \\
\hline 8:06:20 AM & 4 & Keluar & 0 & 0 & Menganggur & Menganggur & Menganggur & \\
\hline 8:06:25 AM & 5 & Datang & 1 & 1 & Sibuk & Menganggur & Menganggur & \\
\hline $\begin{array}{l}8: 08: 13 A M \\
8: 10: 13 A M\end{array}$ & $\begin{array}{l}6 \\
5\end{array}$ & $\begin{array}{l}\text { Dotang } \\
\text { Keluar }\end{array}$ & $\frac{2}{1}$ & $\frac{2}{1}$ & $\begin{array}{l}\text { Sibuk } \\
\text { Menganggur }\end{array}$ & $\begin{array}{l}\text { Sibuk } \\
\text { Mengangur }\end{array}$ & $\begin{array}{l}\text { Menganggur } \\
\text { Menganguur }\end{array}$ & \\
\hline 8:10:23AM & 7 & Datang & 2 & 2 & Menganggur & Sibuk & Sibuk & \\
\hline $8: 12: 14 \mathrm{AM}$ & 8 & Datang & 3 & 3 & Sibuk & Sibuk & Sibuk & \\
\hline 8:12:19AM & 6 & Keluar & 2 & 2 & Sibuk & Menganggur & Menganggur & \\
\hline $8: 13: 50 \mathrm{AM}$ & 7 & Keluar & 1 & 1 & Menganggur & Sibuk & Menganggur & \\
\hline $\begin{array}{l}8: 14: 30 \mathrm{AM} \\
8: 15: 01 \mathrm{AM}\end{array}$ & $\begin{array}{l}9 \\
8\end{array}$ & $\begin{array}{l}\text { Datang } \\
\text { Keluar }\end{array}$ & $\frac{2}{1}$ & ${ }_{1}^{2}$ & $\begin{array}{l}\text { Sibuk } \\
\text { Menganggur }\end{array}$ & $\begin{array}{l}\text { Sibuk } \\
\text { Sibuk }\end{array}$ & $\begin{array}{l}\text { Menganggur } \\
\text { Sibuk }\end{array}$ & \\
\hline 8:16:26 AM & 10 & Datang & 2 & 2 & Menganggur & Sibuk & Sibuk & \\
\hline 8:17:10 AM & 9 & Keluar & 1 & 1 & Sibuk & Menganggur & Menganggur & \\
\hline 8:18:20 AM & 11 & Datang & 2 & 2 & Sibuk & Menganggur & Sibuk & \\
\hline 8:18:44.AM & 10 & Keluar & 1 & 1 & Menganggur & Sibuk & Menganggur & \\
\hline 8:20:18 AM & 12 & Datang & 2 & 2 & Sibuk & Menganggur & Sibuk & \\
\hline $\begin{array}{l}8.20 .31 \mathrm{AM} \\
8.22 .29 \Delta \mathrm{M}\end{array}$ & $\begin{array}{ll}11 \\
13\end{array}$ & $\begin{array}{l}\text { Keluar } \\
\text { Datang }\end{array}$ & $\begin{array}{l}1 \\
2\end{array}$ & $\begin{array}{l}1 \\
2\end{array}$ & $\begin{array}{l}\text { Mengangugr } \\
\text { Sibuk }\end{array}$ & $\begin{array}{l}\text { Menganggur } \\
\text { Menganggur }\end{array}$ & $\begin{array}{l}\text { Sbibuk } \\
\text { Sibuk }\end{array}$ & \\
\hline 8:23.00 AM & 12 & Keluar & 1 & 1 & Sibuk & Mengangaut & Mengangout & \\
\hline
\end{tabular}

Dari table nilai antrian nasabah dan status antrian teller bank Mega Padang dapat diketahui yang akan dihitung adalah :

1. Average waiting time adalah rata - rata waktu tunggu per customer.

2. Average Queue length yaitu rata - rata pelayanan nasabah

3. Waktu pelayanan nasabah di bank.

Perubahan pernyataan dalam perhitungan akan dipengaruhi oleh :

a. Customer arrivals adalah pelanggan yang tiba.

b. Semua pelanggan sudah selesai dari service tersebut.
Apabila seseorang pelanggan tiba, ia dapat lansung masuk dalam fasilitas service atau masuk dalam antrian. Disebelah lain apabila pelanggan atau service selesai, maka customer yang menunggu dapat lansung masuk ke pelayanan atau kalau sudah habis maka akan terdapat waktu lowong ( idle time) pada service facility.

Dengan ini akan diperlukan informasi untuk mengatahui berbagai kondisi yang muncul pada teller yang sibuk dan menganggur. Perhitungan teller menganggur dengan mengurangi waktu mulai sibuk dengan waktu teller mulai menganggur. 


\section{KESIMPULAN}

1. Bank Mega Padang memiliki struktur atau layout dari jumlah antrian adalah tunggal atau single, dan saluran (channel) adalah sebanyak 3 teller, berarti lebih dari satu saluran (multiple). Tingkat pelayanan yang diberikan adalah tunggal atau single. Dengan demikian struktur dan tingkat pelayanan di Bank Mega Tbk adalah "Multiple Channel Single Phase" namun akan lebih baik pelayanan kepada nasabahnya dengan nasabah yang antri dalam baris antrian adalah 0 dan kalaupun anggarannya sebanding dengan hasil dari banyak transaksi nasabah.

2. Pola pelayanan nasabah di Bank Mega Padang mengikuti distribusi eksponensial dan panjang antrian nasabah tidak terbatas.

3. Seiring dengan lama waktu teller menganggur,Analisis dan Simulasi Sistem Antrian 65 nasabah, penelitian telah dicapai yaitu manajemen bank mega tidak perlu menambah teller karena banyaknya waktu teller menganggur.

\section{DAFTAR KEPUSTAKAAN}

Dimyati. 1999. Probabilitas Suatu Peristiwa. Jakarta: PT Elex Media Komputindo.

Djauhari. 1990. Teori Probabilitas. Jakarta: Yudhistira.

Djauhari. 1994. Random Eksperiment. Jakarta: Yudhistira.

Gross dan Haris. 2001. Defenisi Antrian Nasabah. Gross: PT. Gramedia Pustaka Utama.

Guttman. 1982. Goodness of Fit. London: Prentice Hall.

Levin. 2002. Karakteristik Antrian. Bandung: PT. Gramedia Pustaka Utama.

Schroeder. 1997. Fasilitas Pelayanan. Jakarta: Erlangga. 